\title{
Decoding Encoded Yorùbá Nomenclature: An Exercise of Linguistic Competence and Performance
}

\author{
Taofeek Olaiwola Dalamu \\ Anchor University Lagos
}

\begin{abstract}
Correspondence concerning this article should be addressed to Taofeek Olaiwola Dalamu, Department of English \& Literary Studies, Anchor University Lagos, Lagos, 1-4 Ayobo Road, Ipaja, Lagos, Nigeria.

E-mails: lifegaters@yahoo.com; tdalamu@aul.edu.ng
\end{abstract}

\begin{abstract}
The proficiency of Yorùbá users has influenced the formation of towns' names, which this study investigated, revealing their haphazard formation processes. Ten towns of Yorùbá-land in Nigeria functioned as exploratory samples. Ellipsis, serving as the analytical instrument, elucidated the effectiveness of competence and performance, being operational in the clipping of statements to nominal lexemes. The study exhibited flexibility in the development of Yorùbá names, influenced by users' needs. The historical facts of business, religion, hunting, war, and conquest supported the formations, without seemingly consistent linguistic principles. The study further revealed the deletion of linguistic components (Ilè tó ń fè $=$ Ilé-Ifè - a piece of land that expands), twists in pronunciations with a meaningless derivative (Ojà kò tà - business is not picking up = Ojóta), manipulation of English words to Yorùbá (Bad agric = bà dá gìrì [Badagry]), and the production of novel lexemes-cum-meanings (Amúkokò - a person who catches a leopard = Amùkòkò - someone who smokes his pipe). Although, individuals might attempt to regulate ways that people employ language to formulate words, the study suggested that language communicators should be allowed to deploy language as pleased. As language analyses seem descriptive, utilizing language as one wishes, might yield novel items which can enhance unique language development.
\end{abstract}

Keywords: arbitrariness, competence, ellipsis, language dynamism, performance

\section{Intorduction}

Various elements characterise the cosmic concept known as language. The universality of its features projects language to be different from other forms of animal communications. Chomsky (1972) rightly justifies and affirms that language is the essence of humanity. Perhaps, if language ceases to exist; human beings' existence might invariably be terminated from the Earth because it is a device that provides leeway for harmonious human existence. Among other variables that contribute to human existence, language seems a prime and significant device. Hence, Kuiper and Allan (1996) describe the properties of language in the form of a coded symbol, functional, arbitrarily creative, productively human, socio-cultural and culturally transmitted from one source to another. It is also a system of systems guided by rules and provides optional choices for its users (Dalamu, 2018c). Besides, one could further depict language as a unique phenomenon that is tense bound, substitutable with words, even with discrete phonemic substances. Language responds to changes any time as a response to its developments (Fromkin, Rodman \& Hymas, 2003, p. 4-7; Adetugbo, 1997, p. 5-7). Similarly, Yorùbá responds to fulfill the needs of its users in that regard. Consequently, the concept of nomenclature is worthwhile among Yorùbá users (Adeoye, 1969). By nomenclature, the researcher refers to organised-cum-cultural manners in which Yorùbá interactants in Nigeria produce the names of towns and places (Yusuf, Olatunji \& Issah, 2014).

Owing to human communicative demands, certain Yorùbá names and places have been modified from their original linguistic statuses to something novel (Oyelaran, 1987). In other words, those names have turned away from their initial appearances to assume new positions. The purpose of convenience, Oduyoye (1972) asserts, influences the changes that occur to the names and towns. First language speakers (L1) are at liberty to deploy 
their language at will without a check from authorities or institutions. ${ }^{1}$ Such freedom-cum-exercise informs the formations and applications of new lexemes in the language's word stock, while some lexicons might also go into extinction (Jones, 1982). The relevance of this study is located in the arbitrary creativity that Yorùbá speakers enjoy, producing universal acceptability. The product of such formative mechanisms demonstrates that the language is responding not only to changes but also to development (Pavlinov, 2015). Thus, this study analyses some modifications that occur to names of Yorùbá places and towns accompanied by linguistic competence and performance. The argument exhibits how the competence of Yorùbá speakers aids their performance to successfully recast referential and historical statements to their current situations. The literature review focuses on the Yorùbá sources, codification and development, and terminologies of competence and performance. Ellipsis functions as the device for the analysis.

\section{Yorùbá's Source, Codification, and Development}

Yorùbá might not have an exclusive written history. McLaughlin (1970) recognizes that fact to comment that the search for the beginnings of language development is an unrewarding enterprise. It is always difficult to talk about beginnings in any serious way; it is much easier to talk about evolution at least somewhere in the middle. As such, the Yorùbá linguistic history perhaps began somewhere in the middle of the 19th century. That refers to the changes that sparked its development. The study began late for a number of possible reasons. It could be that before the advent of Western traders there had been no reliable written records on Yorùbá. It seems that colonial masters and missionaries introduced the Western education that propels tangible written records. Farming seemed more prominent in those days than Western education. Few Yorùbá indigenes were able to cross the border of secondary education to obtain university degrees that could trigger research in the Yorùbá language matters. The few who attended universities might not be interested in research in Yorùbá with a formed-opinion that such might not be lucrative unlike their counterparts that studied English, Law, Medicine, Economics, Engineering, etc. Digging into Yorùbá data might be cumbersome because the data available might be in the form of folklore, myths, or historical literature that are not written documents per se. Most of the Yorùbá forefathers were not lettered in Western education before colonialism. However, ancient Yorùbá people had their own different ways of keeping records. Notwithstanding, the Yorùbá race has produced a number of scholars at home and abroad, who have been making significant marks on the development of the language. Beside Ajayi Crowther, who translated the English Bible into the Yorùbá version, notable scholars have been observing the language from different perspectives and contributing their opinions to its credit. Among other scholars are Bamgbose, Ayo Banjo, Adetugbo, Ojo, Mustapha, and Oyetade.

Historical records report Yorùbá as a Kwa language and one of the 12 Edekiri languages, which belongs to the Yoruboid group (Paul 2009) of Defoid languages of the Benue-Congo, Volta-Congo, and Atlantic-Congo under the Niger-Congo phylum. ${ }^{2}$ The Niger-Congo is the 1419th most spoken language of both the Central and South Africa (UCLA, 2014). The hallmark of Yorùbá, in orthographical tones of three distinctions, forms high, mid, and low characteristic models. Adetugbo (1982) establishes that the high is marked with an acute accent (e.g. á), the low with a grave accent (e.g. à), and the mid tone usually left unmarked. These marks are usually placed on the vowels. In some circumstances the mid tone is indicated with a macron (UCLA, Language Materials Project, 2014). Furthermore, accounts specify that Yorùbá is a dialect continuum that accommodates numerous distinct dialects (Bamgbose, 1966). The inherent demarcations in the Yorùbá dialects, marked in the domains of its pronunciations, lexis, and grammar, Oyetade (1995) articulates, are designed after the Roman alphabet. The socio-cultural traditions of the Yorùbá in the Diaspora inform the differences observed in the available spoken 'Yorùbás.' The discovery of the Yorùbá speakers being located, apart from south-west Nigeria, in Benin, Togo, UK, USA, the Caribbean - Brazil, Cuba, etc (Awoyale, 2008), might not have happened without colonialism and slave trade.

Despite the vileness of colonialism, its positive effects on the Yorùbá language cannot be neglected. One of the gains of colonialism is the pioneering of the codification and studying of the Yorùbá language grammar, Aku, in Sierra Leonean territory in 1849 (African Studies Institute, 2010). Odejobi (2005) claims that for a period of about ten years, the Western Region Ministry of Education set up academic groups to examine the Yorùbá orthography in order to construct a worthwhile standard for the language. A significant outcome, Odejobi

\footnotetext{
1 Bloomer, A., Griffths, P., \& Merrison, A. J. (2005). Introducing language in use: A coursebook. New York, NY: Routledge.

2 Central Intelligence Agency. (2009). The word fact book - Benin. Retrieved from https://www.cia.gov/library/publications/the-worldfactbook/geos/bn.html
} 
exemplifies, was achieved in 1966, which had a formidable impact. Since then, the effect has served as the hallmark of the standard form of Yorùbá that is taught is schools for official engagements (Bamgbose, 1966; Afolabi, Omidiora \& Arulogun, 2013). The codified Yorùbá taught in schools today, Ojo (1977) argues, does not seem similar to any of the Yorùbá dialects. This is on the grounds that no one Yorùbá ethnic group could lay claim to its originality (Mustapha, 1987). The current Yorùbá status is neutral and somehow synthetic. It could also be mentioned that the standard Yorùbá does not totally depend on the popular Oyo dialect. The standard Yorùbá is scholar made, scholarship oriented, and scholarship endowed.

The African Studies Institute (2010) reported that in 1819 Bowdich published the first Yorùbá word list, which introduced the language to linguists. Nevertheless, a substantial Yorùbá vocabulary did not appear until 1828 when Hannah Kilham published a collection of vocabularies from 30 African languages, most of which was gathered in Sierra Leone. By around 1843-1849, Yorùbá had become one of the first West African languages to have a written grammar and a dictionary (UCLA, 2014). The 'Vocabulary of the Yorùbá Language' by Samuel Ajayi Crowther was published in 1843. Further accounts explained (Owolabi, 1995; Ogunremi \& Adediran, 1998; Salawu, 2004) that by 1859, a Yorùbá newspaper appeared, and by 1875, an orthography for Yorùbá had been created by the Church Missionary Society in Lagos, Nigeria. The first written Yorùbá poetry was undertaken in 1905 by the prolific and popular writer Sobowale Sowande. By 1920, Yorùbá literacy witnessed a rapid spread; and that period served as a facilitator for a steady flow of original Yorùbá writing in both prose and verse. The movement to study Yorùbá in the United States began in the 1960s as part of U.S. foreign policy initiatives to spread awareness of previously untaught or rarely taught languages (African Studies Institute, 2010; UCLA, 2014).

In the current terrain, there are scholars who have contributed immensely to the development of Yorùbá. In sincerity, the study of Yorùbá has moved a step forward from its grammaticality and phonologicity to information technology applications. Current efforts of scholars are dominated by the cross-fertilisation of ideas especially where there is interplay between the Yorùbá language and computational domains. The plausibility of Yorùbá in(to) computational horizons is been investigated for possible applications. Of significance is the analysis of Kumolalo, Adagunodo, and Odejobi (2013) on the development of a syllabicator for Yorùbá. The quest was borne out of the claim that Yorùbá belongs to the cadre of under-resourced languages of the world (De Pauw, Wagacha, \& De Schryver, 2007). The study shows Yorùbá as a tonal language and a tool for automatic data processing; such quality could be adapted for speech processing technology (Kumolalo, Adagunodo, \& Odejobi, 2010). Afolabi, Omidiora and Arulogun (2013) make another innovative effort congruent to computer applications. The attempt is to certify Yorùbá as an apparatus for text-to-speech applications. Afolabi, Omidiora and Arulogun observe that Yorùbá acceptability and usability to participants are overwhelming. To this end, this study, as a contribution to earlier efforts, reveals word-formation procedures of Yorùbá towns and cities from a descriptive perspective, pinpointing ways that events such as war, business, etc. have influenced the formations.

\section{Linguistic Competence and Performance}

Noam Chomsky pioneered the concepts of linguistic competence and performance. Chomsky (1965) described linguistic competence as the perfect knowledge that the ideal native speaker-listener (e.g. a Yorùbá speakerlistener) possesses in his/her language in a completely homogeneous speech community. An innate and internalised system of language rules, Chomsky $(1965$, p. 4) stressed, makes possible the untainted knowledge of the language. This is because the L1 naturally understands the tenets of the language from birth, distinguishing well-formed features from deviant ones. Thus, competence is a person's ability to create and understand sentences, including sentences that the individual has never heard before. ${ }^{3}$ Competence also includes the person's knowledge of what are and what are not sentences of a particular language (Malmkjaer, 2004, p. 287; De Beaugrande, 1991, p. 150-151). An actual language user, in Chomsky's (1965) discernment, might not be perfect in constructing the language structures although the individual may have perfect linguistic competence. The reason provided is that language performance is somehow inferior to the knowledge of the language; it is mediated by memory limitations and distractions.

A speaker often seems to speak faster than he/she thinks because the speech may not keep pace with his/her linguistic competence, hence, the making of mistakes. It is added that performance is the innate speaker's actual deployment of the language. 'A difference is made between a person's knowledge of the language (competence)

3 Richards, J., Platt, J., \& Weber, H. (1997). Longman dictionary of applied linguistics. London, UK: Longman. 
and how a person uses the knowledge in producing and understanding sentences (performance)' ${ }^{4}$ When two or more innate speakers-listeners of a particular language have recourse to debate on a particular subject, one could observe that there might be variations in the degree of performance. The variations provide room for labeling some people above-average public speakers. The linguistic performance of language users may fall short of competence because of random and characteristic blunders. Often, performance is a probable imperfect reflection of competence. Particularly, Radford (1988, p. 3) argues that the occasional slips of the tongue in people's everyday conversations do not mean that the individuals do not have a fuller understanding or fluency of their native language.

\section{Theoretical Concept: Ellipsis}

Modification of names (or words) can be realised through word formation processes. Word formation, in Yule's (1985) articulation, is a process where novel items are created from existing words through the processes of coinage, compounding, blending, clipping, backformation, conversion, acronym, derivation, and affixation (Okoro, 2006). Clipping, as a relevant term of this study, occurs in a word, multi-syllabic word or a clustering of linguistic contents so that the constructs can be reduced to a shorter form (Zapata, 2007). Some examples of clipping are: television = telly; brother = bro; professor = prof; Are you going tomorrow? = Going tomorrow?; You come = Come; Will you read in the night? = Read in the night?; I will be there in two hours = Two hours; You are silly = Silly. And Wálé = Wá sí ilé (return home), Șișé = Șe ișé (work), and Rérìn ín = Rín èrín (laugh) are illustrations of Yorùbá instances.

Ellipsis is the theoretical concept with which the clipping modifications in Yorùbá nomenclature - places and towns - are analyzed (e.g. Àwórì = àwó ti rì = the portion where the dish/plate sinks). Pope (1998) explains that the omission of items implicitly understood by the audience is what is known as ellipsis, regularly operational in speeches. The basis is that fragmented structures, in Martin's (2002) manifestation, are effective when the listeners understand the structured text, and are capable of supplying the missing elements in order to link up the speaker's intended meaning. That position is a probable motivation for Pope (1998) to submit that ellipsis is common in about $95 \%$ of human interactions because it is much easier to communicate in speech than in writing for communication in speech is faster and immediate (Adetugbo, 1997).

Moreover, ellipsis is a punctuated cohesive device of several shapes in forming a structural unifying whole. Ellipsis, in Halliday and Hasan's (1976, p. 142) description, is substitution by zero. This term is a principle of brevity, economising textual structures (Cook, 2001, p. 171), a tool of sentential fragmentation (Carter \& Nash, 2013, p. 260), a language user's fundamental power to punctuate a sentence (Myers, 1994, p. 54-5), and a kind of linguistic shorthand. Goddard (2002, p. 107) projects ellipsis as a deletion of core grammatical forms of subject, determiner, generic 'you' as well as the verbal content (Carter, 1997, p. 91). On that note, ellipsis is an act of removing parts of a linguistic substance of a word, a group, or a clause either of a simple appearance or a complex one for a convenient purpose. McGregor (1997, p. 328) argues that 'Ellipsis involves the omission of something which is actually there in a grammatical structure, presuming retrievable from the linguistic or extra-linguistic content. In my mind, two things are principal in ellipsis. The first is deletion. The second is recovery. Deletion is connected to the addresser's mission; while recovery is linked up to the addressee's goal. The interactant, for the purpose of familiarity, curbing time wastages, focusing the core value of the message, and avoiding textual superfluity, tends to remove parts of the statement.

The principle of ellipsis, Cook (2001) says, has some recognizable impacts on users, which are highlighted as the creation of conversational tones, the demonstration of shared knowledge, and the exhibition of social interest between the participants. The influence tends to build cordial relationships between the interlocutors, indicating an informal setting in the communication realm (p. 172-173).

The linguistic content of a sentence can be distributed into what is known as ranks. ${ }^{5}$ The rank scale is categorised into the following segments - morphemes, words, groups, group complexes, clauses, and clause complexes (p. 23). Owing to the sentential appreciation, Quirk and Greenbaum (1973) categorise the fragmentation into ellipsis dependent of linguistic content, ellipsis not dependent on linguistic content, ellipsis of auxiliaries and pro-forms, and ellipsis in coordinated clauses, etc. (p. 251-253, 261-267), whereas the classification of ellipsis, in Halliday and Hasan's (1976) sense, is a bit different from the former. This is because the categorisations

\footnotetext{
4 Ibid., p. 21.

5 Thompson, G. (2004). Introducing functional grammar. London, UK: Hodder Arnold.
} 
are based on the three submissions of nominal ellipsis, verbal ellipsis, and clausal ellipsis. Under the normal, verbal and clausal ellipsis the descriptions of the others are sub-categorised. Nominal ellipsis operates within the confinement of the nominal group (nouns, pronouns, numeratives, epithets, deictic elements, etc.). Verbal ellipsis occurs within the verbal group (operator, polarity, modality, verbal lexis). Clausal ellipsis takes place within modal and prepositional elements, yes/no and wh-questions, indirect responses, etc. (see Halliday \& Hasan, 1976, p. 147-222). Such functional positions have inspired the author to ask the following questions: How do Yorùbá speakers naturally form words in the form of convenience? Can the innate formation processes be justified within the domain of word formation theorisation? Does the word formation processes follow a particular pattern or trend? What are the historical background(s) associated with the formation of Yorùbá town names? Significantly, these will assist in informing readers about some of the contextual trends and revelations of word formation processes of Yorùbá nomenclature.

\section{Methodology}

This study received inspiration from and was triggered by His Royal Majesty, Ọba Ẹnitan Adeyẹe, ọjjájá II, the Oòn uttered in a live telecast some time in December 2015, after his coronation. The Oòni made known that Ilé-Ife. means ilè tó $n$ fè (as exemplified latter). The statement energised the author to conduct a simple research project on the underlying meaning of the names of other Yorùbá places.

\section{Participants}

Forty-two individuals participated in the data collection exercise of the research. Thus, the participants could be classified into three distinct categories: the author, the guide/leader, and the narrators. Apart from the guide, who was just one person (Bonke), the narrators were 40 individuals, who preferred to remain anonymous. Bonke was about 36 years old, while the narrators' ages were between $70-80$ years old in order to obtain accurate historical information about the towns. The choice of Bonke rested on her driving dexterity and impressive knowledge of the towns and cities of South West, Nigeria where the Yorùbá people live (Bamgbose, 1966; Adetugbo, 1982). To reiterate, the 40 narrators were responsible for the histories of the selected towns.

\section{Research Design}

Following Litosseliti (2010), Patton (2015), and Dalamu (2017b), the sampling procedure was adopted as a means of making a suitable choice for data analysis. The sampling method permitted me to select 10 relatively handy numbers of towns from a large defined population of 20 towns (Nwagugo \& Anumnu, 2003). The sampling technique enhanced the reduction of costs, speed of analysis, and discourse accuracy. The decision to select 10 towns was based on the matter of appropriateness, the nature of the formation, and meaning derivatives of the names of the towns. In that regard, I stratified and delimited the population of 20 names of towns into 10 parts, where one town was chosen from each unit.

\section{Measures}

The ten preferred towns, which operated as the strata in the investigation, functioned as illustrations of the production of names' modus operandi in South West, Nigeria. Being a Yorùbá person, my knowledge of the language aided the choice of examining the word-formation processes of the towns. I already knew some information, though faint and unreliable, about the histories of the towns. Nonetheless, this research stimulated me to meet some elders, as a surveying exercise, in order to secure the true histories of the towns. I achieved my research goals through interviews, where writing materials such as notebooks and pens were utilised to jot down the information that the elders provided.

\section{Procedure}

In reference to the lexemic formation method as well as the meaning making potential, I categorised the names into 10 segments. As stated earlier, it was from each group that 10 names, according to their contents, served as the elements-cum-structures of analysis. The guide, who has been my 'partner in progress' in data collection, 
collected an average of $20,000.00$ (' $\$$ ' is the sign of the Nigerian currency) from me as we travelled to places such as İgbesà, ògbómòsó, and Iléșà. However, the guide received only $\$ 10,000.00$ as compensation for data collection within Lagos arenas. The funds were for car maintenance and meals. The 40 elders involved in the interviews donated their time to the project. Nevertheless, for reasons of comfort, appreciation, and pleasure, I spent about $12,000.00$ to host a set of two elders in each town that we visited during the interviews. Seaman Schnapps $^{\circledR}$, classified as a drink for elders (Dalamu, 2017a), and other menu items were entertainment provisions for motivating the narrators. The need for concise histories necessitated the choice of two elders in each town. Truly, it was Bonke that located and organised the elders, who were community leaders and very versatile in the historical background of the selected towns.

After the presentation of data, as demonstrated in Table 1, below, in terms of 'statement', 'translation', and 'end product', the terminology of ellipsis (Napoli, 1996) negotiated through the linguistic notions of competence and performance (Chomsky, 1965; Malmkjaer, 2004) in an LI situation, was utilised to process the texts. I approached the results and discussions through word-formation patterns, theoretical connections, and viable historical contexts. ${ }^{6}$

Table 1

Transition of Yorùbá statements into compressed names

\begin{tabular}{|c|c|c|}
\hline STATEMENT & TRANSLATION & END PRODUCT \\
\hline Ilè tó $\boldsymbol{n}$ fê, & A piece of land that expands & Ilé-Ifè, \\
\hline Ọjà kò tà & Business not picking up & Ojóta \\
\hline Ìgbo igi là & Gaining blessings while searching for firewood & İgbógílà. \\
\hline ògbórí Ẹlémòșó, & One who cuts Elémòsó's head & Ògbómòșó \\
\hline ilè àwọn olórìșà tí a șà s'ótò fún òrì̀à bíbọ & A place set aside for idol worshippers & Iléșà \\
\hline amú ìkokò, ajeegun jẹran. & One who catches a leopard & Amùkòkò \\
\hline ègbé òsà, & Near the lagoon & İgbẹsà \\
\hline di òpè mú & Hold on to òpèlè (Ifá operational tool) & Dòpèmú \\
\hline oní awùsá or alá wùsá. & A place where walnuts grow & Aláúsá \\
\hline Bà dá gì rì & Bad agricultural area & Badagry \\
\hline
\end{tabular}

\section{Results and Discussion}

Yorùbá society influences, in many ways, the linguistic structures of the language that its speakers deploy to execute certain communicative projects. As mentioned earlier, one observes such functions in the manner that the names of Yorùbá villages, towns, and places are formed. Thus, these discussions follow after the ways that social concerns have informed the structural contents and organisations of the formation procedures of the selected names and towns (Cooley, 1902; Mead, 1934). As one understands that traditional behaviours and language are interdependent (Kress, 1981), the notion of competence and performance has influenced the patterns of the Yorùbá word formation practices. ${ }^{7}$ The methods, as explicated below, utilise ellipsis as an explanatory paradigm, revealing to readers the formation systems in the form of elimination, twisting and replacement, as associated with some historical facts. In that course, a whole new name emerges after a long time of conversational usages.

\section{Ilé-Ifè}

Ilè tó ń fề, refers to "a piece of land that expands". A Yorùbá cultural connotation impinges on a belief that a piece of land expands, which could be contrary to logic, philosophy, and natural sciences. The view could have a link with the thought of Yorùbá spiritual perception, seeing Ilé-Ifè, as their origin from where the race migrated to several locations to establish some villages (that tend to become towns) for the purpose of expansion (Bamgbose, 1986). The Yorùbá nationality began to expand from the source, Ilé-Ifè, to many parts of the world. The structure, ilè, $\boldsymbol{t o ́ n} \boldsymbol{n}$ fề, has been clipped by omitting certain linguistic elements to produce Ilé-Ifè, (Booij, 2007). The choice is a

\footnotetext{
6 Zapata Becerra, A. A. (2000). Handbook of general and applied linguistics. Mérida, Venezuela: Trabajo de Ascenso sin publicar.

7 Thompson, G. (2014). Introducing functional grammar. Abingdon, UK: Routledge.
} 
result of removing tó $n$ from the middle of the entire structure to form Ilé... Ife. For the reason of competence in the language, $\boldsymbol{i}$ is introduced to 'fè to become Ifè. Then, the combination of the items Ilé and Ifè is what is popularly known as Ilé-Ifè, nowadays.

Ilé-Ifè seems to be ambiguous in meaning. First, Ilé-Ifè, could mean "home of expansion" and second, "home of love", that is, Ilé İfé (Yuzhannikova, 2015). Irrespective of one's school of thought, two of the potential constructs are culturally meaningful and perhaps appropriate (Gumperz \& Cook-Gumpez, 2008). On the one hand, "home of expansion" goes along with the explanation that the new Oòni of Ifè gave after his coronation ceremony. That thought seems sacrosanct for the knowledge of His Royal Majesty on the tradition of Ifè (the short form of Ilé-Ifè). In fact, the Royal Father is the custodian of the Ife traditional antiquities. On the other hand, an analyst could portray "home of love" as a strong feeling of caring that somebody has for another person. As much that there are no legislative principles that guide and protect the formation; it is not an understatement to say that ilè tó been clipped (Bauer, 1983; Nolda, 2014) to produce Ilé-Ifè, the Yorùbá cradle. Who knows whether in a couple of years, owing to the dynamic nature of language, Ilé will be removed from Ilé-Ifè, and only Ifè, will be required for identifiable communication.

\section{Ọjóta}

Yorùbá naming methodology is quite amazing, especially if one digs into the history as a para-historian (Akinnaso, 1980). An analyst might be led to believe that virtually every Yorùbá name is a statement. That is why, a Yorùbá person is first and foremost identified by his name. Nonetheless, Islam and Christianity have consistently influenced Yorùbá names. Every name is syllabically meaningful, and perhaps, connected to a certain event (Owolabi, 1995). Ojà kò tà illustrates the argument for being unconsciously systematically converted to Ojóta, a town in Lagos State. As displayed in Table 1, above, ojà kò tà means "business is not picking up." The historical background correlating to the statement might be that the place named ojóta was a market place in those days. However, farm produce and other invaluable items that were usually brought to be sold in the market could not be sold on time unlike other markets where similar goods were taken. In the course of time, while the language users employed ojà kò tà in their daily conversations; it then turned to ojót $t a$. Structural-wise, the clipping formation (Bauer, 2001) of the end product, $O j$ jot $t a$, does not in any way follow any theoretical elliptical implement. Convenience dictates the process of formation.

In the statement, ojà kò tà, oj is retained from the lexeme, ojà (market), and kò is totally removed from the statement (Ajiboye \& Armoskaite, 2015). An intrusive $o$ is introduced to fall within the norm of the desire of the language users. The collapsibility of $a$ and kò, and the introduction of $o$ between the remaining element $o j$ ' and tà leaves us with $0 j$ jóta. The structural formation goes thus: $o j+\grave{o}+t \grave{o}=0 j$ jóta. The formation is a result of the vitality that one can expect from language. The product is trilling. Commendations go to both the language users and the characteristics of Yorùbá that permit listeners to observe competence and performance in this way.

\section{Ìgbógílà}

İgbo igi là is the next item in this discourse. The statement means "prosperity comes in search of firewood." History has it that a hunter left a place where an individual had been sojourning for a long time in search of firewood. Fortunately for the hunter, the person came across a river, and then the individual decided to establish himself and family near the river. Thus the hunter abandoned his former domain where enough water was not available. That singular act was to the hunter remarkable and a blessing. The water that the hunter saw while in search of firewood became a source of comfort. The individual had no intention of looking for a river, but the search for firewood pushed him to gain an advantage. The activity igbo igi became a privilege, là (prosperity) for the individual. The clipping system (Arnoff, 1976) indicates that only $i$ is deleted from the middle lexeme, igi and remains 'gi. The lexeme igbógilà, is then produced from the combination of ighbo + 'gi + là. İgbógílà is a town in Egbado North, Ogun State, Nigeria. In the final production of the name, the sound no longer reflects the meaning. It has become artificial (Okanlawon, 2017). Except for those who are enlightened regarding the historical details of the town, it is a great task to decode the real meaning from the pronunciation of the name. The meaning is (by tone mark) ìgbogilà, however, it is pronounced İgbógílà.

\section{ògbómòsó,}

ògbómòsó, a renowned town in Oyo State, is produced from the clipping exercise that ògbórí Elémòsó underwent. 
ògbórí Elémòsó could be translated as someone who carries the head of Elémòsó. The profound meaning is perhaps somebody who succeeded in defeating the people's enemy at war (as in the case of David and Goliath in the Holy Bible), cut off the head, and showed it to the fowls of the earth. In Yorùbá history, two warriors were engaged in a fight that lasted for some seasons. The more popular between the two was Elémòsó, a cunning warrior. Unfortunately, Elémòsó was defeated by his antagonist. The antagonist cut off Elémòsó 's head after the fight and showed it to the people (Chernow \& Vallasi, 1993; Gecas \& Burke, 1995). The place where Elémòsó's head was shown to the people is called ògbórí Elémòssó. The name is in honour of the killer of Elémòsó It is quite unfortunate that the name of the triumphant warrior is not renowned unlike his act of conquering the enemy, Elémòsó. Ògbómòsós's word is produced by linguistic shorthand (Haspelmath, 2002) through the removal of rí from the first text, oggbórí and retaining ògbó'; and Elé is also deleted from the textual element of Elémòsó to remain

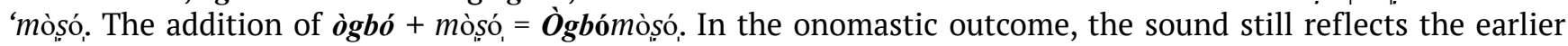
intended meaning of ògbórí Elémòsósó.

\section{Iléṣà}

What is known in Yorùbá land as Iléșà today was coined from ilè àwọn olórị̀à and by extension, it was ilè olórìșà. That is ilè àwọn olórìsà tí a șà s'ótò fún órìsà bíbọ. The two statements could be interpreted as "a piece of land separated for worshippers of deities." The idol worshippers that numbered about seven, happened to be powerful people, that were not entitled to become kings (Rymes, 1996). Their sole function informed setting aside a piece of land for the priest, without the interruption of the people, to be conveniently performing spiritual rites. The situation of these idol worshippers in the Yorùbáland could be compared to the British Colony, Australia, where convicted criminals were kept and managed (Jackson \& Ze Amvela, 2003, p. 124) that later turned into a country of fortune that accommodates responsible people and erudite intelligentsia such as: Halliday, Hasan, Matthiessen, Yallop, etc. Although ilè àwọn olórìsà is longer and more meaningful, courtesy demands that the convenience of the people should be fundamental. Therefore, the statement was clipped to Iléșà. The structural outcome of Iléșà is found in the brevity principle (Kelley, 2006) by the removal of àwon olórì from the statement. However, the first word, ilé in connection with the last component 'sà of the last word olórìsà is considered for the production of Ilésà. Meanwhile, the original ilè (land) has turned to ilé (house) in the current realization. The twist might serve as a means to achieve expediency.

\section{Amùkòkò}

Amùkòkò is the name of a town in Lagos State. By listening to the pronunciation of Amùkòkò, a different meaning is deducible from the way that the town is pronounced nowadays. The current pronunciation will sound like "someone who smokes his pipe". Nevertheless, the true semantic derivation of the lexeme Amúkokò is "a person who catches a leopard.” The Yorùbá original word is amú ikokò. This investigation mirrored earlier findings that language is lively; as time goes on and human beings grow, language also grows and changes (Okoro, 2006). Amú ikokò (hunter) is a good example of a language change that has been turned to Amùkòkò (smoker). The lexemic fragmentation is not too huge. Two things occurred in the word-formation process. One the $\boldsymbol{i}$ in $\boldsymbol{i k o k} \boldsymbol{o}$ is ellipted. Two, both amú and ikokì are clipped together as a single word (Katamba \& Stonham, 2006). What is known as Amùkòkò in Lagos today is a derivative of amú ikokò, ajeegun jeran. A leopard is characterised as a special animal that eats both the bones and flesh of animals.

\section{Ìgbẹsà}

Yorùbá seems to be a language that does not construct texts just for structure's sake. Despite that normative quality, our forefathers were not well-lettered in Western education, meanings of phenomena seemed so important to ancient Yorùbá people. One observes such behaviours in several constructs of the language. For instance, names in Yorùbá are traditionally customised and socially conjectured (Akinnaso, 1981; DePaulo, Kenney, Hoover, Webb \& Oliver, 1987). İgbẹsà as an Àwórì town was fabricated along that line. İgbẹsà was a product of ègbé òsà, which means 'by the side of the lagoon.' The implication of the name evolved because of a river that has been linked to the Lagos lagoon and by its side a dwelling was established. The tradition is embedded in the relationships between the river and settlement. The writer notices the social conjecture of İgbesà in the arbitrary substitution of $\grave{e}$ in ègbé, for an intruder $\grave{i}$ (Blumer, 1969). The swap turns ègbé, to igbee. One also observes that $\grave{o}$ in òsà removed, leaving only 'sà. The combination of the lexemes ìgbe and 'sà obtains the morphological realization of Ìgbesà. Arbitrariness of this creativity is in the manner in which words are haphazardly substituted, where one linguistic component gives way for another to replace it (Dalamu, 2018a; 2018e). 


\title{
Dòpèmú
}

$D i$ òpè mú is a statement that turns to Dòpèmú after a continuum, non-spatial usage among the Yorùbá speakers. This construction acknowledges an established fact in the linguistic domineering world that one cannot totally separate the culture of the people from their language. This is equivalent to the Sapir-Wholf hypothesis of linguistic determinism (Yule, 2016). One could only trace the recurring change from di òpè mú to Dòpèmú. However, its conversion validity might be difficult to formalise. The date people began to call it Dòpèmú might not be unravel-able, nonetheless, one is only sure that the novel lexeme emanated from di òpè mú. An analyst might posit that di òpè mú is an ambiguous statement (Denham \& Lobeck, 2013). The ambiguity resides in the central word òpè. Two meanings evolve here. One, òpè in the Ègbá dialect means "palm tree." If one goes by that, di ò è $_{\text {, }} u ́$ would mean "hold on to palm tree." The second version that seems more relevant, meaningful, preferable, and practical is to consider òpè as a short form of òpèlè. Without being clipped, òpèlè relates to the Ifá oracle in Yorùbáland, which is a prophetic device in the custody of an Ifá priest (Pogoson \& Akande, 2011). $\dot{o} p$ èlè is a nonliving device (but spiritually living) that assists to unknot future events to the people, who care

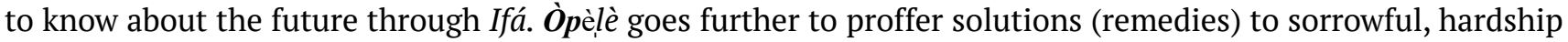
situations, and unforeseen circumstances that traumatise the people (Adegbindin, 2014). In this vein, di òpè mú means "hold on to Ifá oracle" probably in terms of its prophetic truth, service or worship. Descendants of Ifá worshippers bear names such as this. This willy-nilly word-formation is simple because it is only the $i$ that supports the lexeme $d i$, which has been taken away, leaving the organ as $d^{\prime}$. The $d^{\prime}+$ òpè $+m u ́$ combinatory utility produced Dòpèmú as its result.

\begin{abstract}
Aláúsá
The unpredictability of Yorùbá lexemic formation has also touched the statement oní awùsá. A native speaker can understand Oní awùsá as alá wùsá. Discussants have deduced and earmarked two potential meanings from Aláúsá. These forms are: (i) the owner (possessor) of walnuts; (ii) a place where walnut trees grow. Thus, the author will not considerably flex his muscles on either of these options because a number of debates have been held via the local electronic media on the matter and tangible corrections have been made several times that Aláùsá is a place where walnut trees grow and yield fruits. Still on the same line of thought, it is pertinent to state clearly that language is for the people to communicate with one another and not a reversal of it (Dalamu, $2018 \mathrm{~b}$ ). So, that persuasion allows people to dictate forcefully what language is, and operations that the language is meant to perform for interactants. The original meaning of Aláùsá - a place where walnut trees grow - has been hijacked and overturned through the pronunciation currency, which provides different meanings in its entirety (Okoro, 2006). Now, it is Aláúsá. This means as a place where the Hausas (a nationality in Nigeria) live or Hausa's abode.
\end{abstract}

The purpose of studying an event, one can quickly submit, is to have its understanding in order to see how it could positively affect the lives of the people (Swale, 1990). Language concerned institutions ought to let individuals utilise the language the way people want the language to be disseminated, most especially, when such communication contains neither grammatical infelicities nor syntactic errors (Sofola, 1970; Fayeye, 2006). Moreover, what those places are called today does not have a negative effect on the people or on the cities. Languages and discourse communities do not exist as such, as Halliday, Teubert, Yallop, and Cermáková (2004) remark, language and linguistic geography are social constructs. Interactants construe language to suit particular purposes (p. 114). People in authority should allow the liberty of 'the freedom of speech' to thrive in Yorùbá nomenclature. There is no amount of correction in the media that can change the people's will concerning their social discourse of interaction and relationship constructions. It is very significant to understand that there is no formula in the world that can compel people to agree on what a language is and what a language community is. It is up to language users to design formulas in agreement with their intentions, experiences, and what seems useful at a given time (ibid., p. 115). There is a need to learn from the challenge that the restrictive legislation of French and Italian languages has posed on their spread, especially when compared to the global spread of English (Jackson \& Ze Amvela, 2003, p. 28). The global hegemony of English in world affairs (Dalamu, 2018d) could not have been achieved, perhaps, if not for the application of the Feyerabend Principle of 'anything goes' (Feyerabend, 1970, p. 10). There is wisdom in allowing people to do things in a naturally convenient way; such liberty of communication, in Yule's (1985) sense, could yield remarkable results. 


\section{Badagry}

A historical report states that the place Badagry is neither an English nor Yorùbá token. Badagry is rather a grotesque formation emanated from the two languages (Liseli, 2012). During colonialism in Nigeria, the place was tagged as bad land for agricultural production and in short realised as "bad agric area." The Yorùbá speakers, who might not have the English grammatical ethos and ability to realise the place as "bad agricultural area", attempted to convert the same statement to bà dá gìrì. There is elliptical fragmentation in the annihilation of "c area" from "bad agric area" to have bad agri. The nature of Yorùbá morphology pinpoints the constant romance of consonant with vowel (Olmsted, 1951). That is, VCV, CVCV, VVCV, CVV, CV, etc. except in situations of $m, n, g b$ and $k p$, hence, the introduction of $i$ between the consonants $g$ and $r$, which produces girì to listeners. The clipping of bà dá gìr together after the processes of substitution by zero (Halliday \& Hasan, 1976) and the introduction of $\grave{\imath}$ produced bàdágìrì, that is bà + dá + gì $+r \grave{i}=$ bàdágìrì. The continuum usages of bàdágìrì in both spoken and written language emerged as Badagry, without relevant meaning to the lexicon's employment today. The analyst could add that Badagry in its appearance is undertoned in both English and Yorùbá. Bàdá is Yorùbá, while gry is English. Gry cannot locate a functioning zone in Yorùbá phonology; the structure cannot take Yorùbá tone mark because three consonantal elements might not function in Yorùbá consonant cluster without an intrusive vowel sound. Gry, in relation to English, is graphologically possible and phonologically realisable. Looking at the lexeme's phonology, there is gry as /gri:/ (Roach, 1991, p. 67-74; Clark \& Yallop, 1995, p. 67-9; Adetugbo, 1998, p. 68-75). This comparative brevity shows that the construct, Badagry, seems to emanate from the Yorùbá-English distortion capability.

\section{Conclusion}

The study has discussed Yorùbá nomenclature as an arbitrary social phenomenon. Convenience informed the capricious principles witnessed, nonetheless, leading to language growth and development, as recapitulated in the following expressions. One, observations indicate a form of clipping exercises in the ten names examined. Clipping operates in the form of fragmentation and deletion of linguistic components from the middle. Examples are in Ilé-Ifè (Ilé... Ifè), İgbógílà (İgbó ... gílà), and Iléșà (Ilé... șà). İgbesà is exceptional to this recurrent behaviour because clipping through punctuation occurs from the first linguistic facility and the middle. That is (...gbe ... sà). Two, as some linguistic structures are chopped up, others have attracted novel elements to the constituents in order to yield meaningful results. The instances are: Ilé ... [i]fè (with the introduction of letter $i$ ), oj ... [ó]ta (with the introduction of letter ó) and [i] gbe ... sà (with the introduction of letter $i$ ).

Three, there are twists and zigzaggedness in the pronunciation of some of the formations as identified with tone marks, as observed in İgbogilà to İgbógílà, ojà kò tà to Ojóta, and Aláùsá to Aláúsá. Four, although, the historical undertone of Ilé-Ifè might be illogical for scientific evidence, the other analysed towns have historical records. Traditional beliefs project the historical content of Ilé-Ifé, ojóta, and Aláúsá anchor on business transactions of agricultural produce. The analysis reveals hunting, war, and conquest as the historical reports of Amùkòkò, İgbógílà, and ògbómòsó; religious undercurrents produce Ilésà and Dòpèmú respectively; whereas Badagry displays farming as its viable informative content. Given these observations, it is important to allow the formation exercises of Yorùbá users to prevail for proper analysis-cum-codification in order to promote descriptivism. However, further studies could be conducted in the domain of phonological appreciations of word-formation procedures in Yorùbá.

\section{Acknowledgements}

I love to appreciate Prof. Elena Tikhonova for her patience and decision to ensure that this research is published, in no any other journal, but the reputable Journal of Language and Education (JLE). It is also in a similar spirit that I appreciate Tim Thompson for putting the finishing touches to the work. I will also commend the efforts of the reviewers as well as the entire team of JLE for their contributions towards this article. I am so grateful for all your help. 


\section{References}

Accredited Language Series. (2016). Yoruba. Retrieved from https://www.alsintl.com/resources/languages/ Yoruba/

Adeoye, C. L. (1969). Oruko Yoruba. Ibadan, Nigeria: The Caxton Press Ltd.

Adetugbo, A. (1997). English phonetics: A course text. Yaba, Lagos, Nigeria: University of Lagos Press.

Adetugbo, A. (1982). Towards a Yoruba dialectology. Yoruba language and literature. Ibadan, Nigeria: University of Ibadan Press.

Adeyanju, A., Omotosho, I., \& Fatunde, M. (2015). Development of a Yoruba language e-tutor for Windows phone. African Journal of Computing \& ICT, 8(3), 135-140. Retrieved from http://www.ajocict.net/uploads/ V8N3P15-2015 AJOCICT.pdf

Afolabi, A., Omidiora, E., \& Arulogun, T. (2013). Development of text to speech system for Yoruba language. Innovative Systems Design and Engineering, 4(9). Retrieved from http://www.slideshare.net/AlexanderDecker/ development-of-text-to-speech-system-for-yoruba-language

African Studies Institute. (2010). Yorùbá online: African Studies Institute University of Georgia. Retrieved from http://www.africa.uga.edu/Yoruba/yorubabout.html. https://www.alsintl.com/resources/languages/Yoruba/

Akinnaso, N. F. (1980). The Socio linguistic basis of Yoruba personal names. Anthropological Linguistics, 22(7), 275-304.

Akinnaso, N. F. (1981). Names and naming principle in cross-cultural perspectives. Names, 29, 37-63.

Arnoff, M. (1976). Word formation in generative grammar. Cambridge, MA: MIT Press.

Awoyale, Y. (2008). Global Yoruba lexical database, 1.0 Linguistic Data Consortium. Philadelphia, PA. Retrieved from http://www.ldc.upenn.edu/Catalog/docs/LDC2008L03/Global_Yoruba_Lexical_Database.pdf

Babarinde, O., \& Ahamefula, N. (2013) Morphophonological deviation in Yoruba: Its implication for communication. Research on Humanities and Social Sciences, 3(14). Retrieved from http://www.slideshare. net/AlexanderDecker/morphophonological-deviation-in-yoruba-its-implication-for-communication

Balogun, T. A. (2013). An endangered Nigerian indigenous language: The case of Yorùbá language. African Nebula, 6. Retrieved from http://nobleworld.biz/images/6-Balogun_s_Paper.pdf

Bamgbose, A. (1966). A grammar of Yorùbá. West African language monographs 5. Cambridge, UK: University Press.

Bamgbose, A. (1986). Yoruba: A language in transition. J. F. Odunjo Memorial Lecture Series. Ibadan, Nigeria: Molukum and Co.

Bauer, L. (1983). English word-formation. Cambridge, UK: Cambridge University Press.

Bauer, L. (2001). Morphological productivity, Cambridge, UK: Cambridge University Press.

Bloomer, A., Griffths, P., \& Merrison, A. J. (2005). Introducing language in use: A coursebook. New York, NY: Routledge.

Blumer, H. (1969). Symbolic interactionism. Englewood Cliffs, NJ: Prentice-Hall.

Booij, G. E. (2007). The grammar of word: An introduction to morphology. Oxford, UK: OUP.

Carter, R. (2002). Investigating English discourse: Language, literacy and literature. New York, NY: Routledge.

Carter, R., \& Nash, W. (2013). Seeing through language. Lexington, KY: Blackwell.

Central Intelligence Agency. (2009). The word fact book - Benin. Retrieved from https://www.cia.gov/library/ publications/the-world-factbook/geos/bn.html

Chomsky, N. (1965). Aspects of the theory of syntax [Aspects]. Cambridge, MA: MIT Press.

Chomsky, N. (1972). Language and mind. New York, NY: Harcourt, Brace, Jovanovich.

Clark, J. \& Yallop, C. (2006). An introduction to phonetics and phonology. Oxford, UK: Blackwell.

Cook, G. (2001). The discourse of advertising. New York, NY: Routledge.

Cooley, C. H. (1902). Human nature and social order. New York, NY: Charles Scribner's Sons.

Dalamu, T. O. (2017a). Contextualizing advertising as a communicative apparatus of text-switching. Studies in Linguistics, 42, 249-274.

Dalamu, T. O. (2017b). A discourse analysis of language choice in $M T N^{\circledR}$ and Etisalat ${ }^{\circledR}$ advertisements in Nigeria (Unpublished Doctoral thesis). University of Lagos, Yaba, Lagos, Nigeria.

Dalamu, T. O. (2018a). Exploring Advertising text in Nigeria within the framework of cohesive influence. Styles of Communication, 10(1), 74-97.

Dalamu, T. O. (2018b). Euphemism: The commonplace of advertising culture. Acta Scientiarum. Language and Culture, 40(2), 1-15.

Dalamu, T. O. (2018c). Illuminating systemic functional linguistics as a viable tool of digital humanities. Digital 


\section{DECODING ENCODED YORÙBÁ NOMENCLATURE}

Studies/le champ numerique (in press).

Dalamu, T. O. (2018d). English: The new tower of Babel. Alfa: Revista de Linguística (in press).

Dalamu, T. O. (2018e). English language development in Nigerian society: A derivative of advertising communications. Complutense Journal of English Studies, 26, 263-286.

De Beaugrande, R. (1991). Linguistic theory: The discourse of fundamental works. London, UK: Longman.

Denham, K., \& Lobeck, A. (2013). Linguistics for everyone: An introduction. Singapore, SG: Wadsworth, Cenage Learning.

DePaulo, B. M., Kenney, D. A., Hoover, C. W., Webb, W., \& Oliver, P. (1987). Accuracy of person perception: Do people know what kinds of impressions they convey? Journal of personality and social psychology, 52, 303-315.

De Pauw, G., Wagacha, P. W., \& De Schryver, G. M. (2010). Automatic Diacritic Restoration for Resource-Scarce Languages. In V. Matoušek \& P. Mautner (Eds.), Lecture Notes in Artificial Intelligence (LNAI), subseries of Lecture Notes in Computer Science (LNCS) (Vol. 4629, pp. 170-179). Berlin, Germany: Springer-Verlag.

Fayeye, J. O. (2006). Memorial: What's in a name. Ilorin Journal of Sociology, 2(1), 217-230.

Feyerabend, P. K. (1970). Against method. London, UK: Verso.

Fromkin, V., Rodman, R., \& Hymas, N. (2003). An Introduction to language. Boston, MA: Heinle, Thomson.

Gecas, V., \& Burke, P. J. (1995). Self and identity. In K. Cook, G. A. Fine \& J. S. House (Eds.), Sociological perspectives on social psychology (pp. 41-67). Boston, MA: Allyn and Bacon.

Goddard, A. (2001). The Language of advertising. London, UK: Routledge.

Gumpez, J. J., \& Cook-Gumpez, J. (2008). Studying language, culture, and society: Sociolinguistics or linguistic anthropology? Journal of Sociolinguistics, 14(2), 532-545.

Halliday, M. A. K., \& Hasan, R. (1976). Cohesion in English. Edinburg, UK: Longman.

Halliday, M. A. K., Teubert, W., Yallop, C., \& Cermáková, A. (2004). Lexicology and corpus linguistics: An introduction. London, UK: Continuum.

Halliday, M. A K., \& Hasan, R. (1976). Cohesion in English. London, UK: Longman.

Haspelmath, M. (2002). Understanding Morphology. London, UK: Arnold.

Jackson, H., \& Ze Amvela, E. (2000). Words, meaning and vocabulary: An introduction to modern English lexicology. London, UK: Continuum.

Jones, E. D. (Ed.). (1982). African Literature Today. London, UK: Heinemann.

Katamba, F., \& Stonham, J. (2006). Morphology. New York, NY: Library of Congress.

Kress, G. (Ed.). (1981). Halliday: System and function in language. London, UK: Oxford University Press.

Kuiper, K., \& Allan, W. (1996). An Introduction to English language: Sound, word and sentence. New York, NY: Palgrave.

Kumolalo, O. F., Adagunodo, R., \& Odejobi, A. (2010). Development of a syllabicator for Yorùbá language. Retrieved from http://ifecisrg.org/sites/default/files/articles/SYoruba_\%20syllabicator_4.pdf

Lewis, P. M. (Ed.). (2009). Ethnologue: Languages of the world (16th edition). Dallas, TX: SIL International. Retrieved from. http://www.ethnologue.com

Liseli, A. F. (2012). African names and naming practices: The impact slavery and European domination had on the African psyche, identity and protest (Unpublished Master of Art Thesis). Ohio State University, Columbus, OH.

Litosseliti, L. (Ed.). (2010). Research methods in Linguistics. London, UK: Continuum.

Malmkjaer, K. (Ed.). (2004). The linguistics encydopedia. London, UK: Routledge.

Martin, J. R. (2002). Cohesion and texture. The handbook of discourse analysis. New York, NY: Blackwell Publishing.

McGregor, W. B. (1997). Semiotic grammar. London, UK: Oxford University Press.

McLaughlin, J. M. C. (1970). Aspects of the history of English. New York, NY: Holt, Rinehart and Winston, Inc.

Mead, G. H. (1934). Mind, self, and society. Chicago, CH: University of Chicago Press.

Myers, G. (1994). Words in ads. London, UK: Arnold.

Napoli, D. (1996). Linguistics. Oxford, UK: Oxford University Press.

Nolda, A. (2014). Word-formation types definition, identification, classification. Retrieved on 13 June 2018 from http://andreas.nolda.org

Odejobi, O. (2005). A computational model of prosody for Yoruba text-to-speech synthesis (Unpublished Doctoral thesis). Aston University, Birmingham, UK.

Oduyoye, M. (1972). Yoruba names. Ibadan, Nigeria: Daystar Press.

Ogunremi, D., \& Adediran, B. (Eds.). (1998). Culture and society in Yorubaland. Ibadan, Nigeria: Rex Charles.

Okoro, O. (2006). Category shift in Nigeria English. LARES: A Journal of Language \& Literary Studies, 15(1\&2), $10-16$.

Owolabi, K. (1995). More on Yoruba prefixing morphology. In K. Owolabi (Ed.), Language in Nigeria: Essays in honour of Ayo Bamgbose (pp. 92-112). Ibadan, Nigeria: Group Publishers. 
Owolabi, K. (Ed.) (1995). Language in Nigeria: Essays in honour of Ayo Bamgbose. Ibadan, Nigeria: Group Publishers.

Oyelaran, Q. (1987). Ona kan ko woja: Mofoloji Yoruba. Yoruba: Journal of the Yoruba Studies Association of Nigeria, 1, 25-44.

Patton, M. Q. (2015). Qualitative research and evaluation methods: Integrating theory and practice (4th ed.). Thousand Oaks, CA: Sage.

Pavlinov, I. Y. (2015). Why do we call them such way: Taxonomic theory and nomenclature. Priroda, 12, 28-35.

Pope, R. (1998). The English studies book. London, UK: Routledge.

Quirk, R., \& Greenbaum, S. (1973). University grammar of English. Essex, UK: Longman.

Radford, A. (1988). Transformational grammar: A first course. Cambridge, UK: Cambridge University Press.

Roach, P. (1991). English phonetics and phonology. Cambridge, UK: Cambridge University Press.

Rymes, B. (1996). Naming as social practice: The case of little creeper from Diamond Street. Language in society, 25, 237-260.

Salawu, A. (2004). The Yoruba and their language newspapers: Origin, nature, problems and prospects. Studies of Tribes and Tribals, 2(2), 97-104.

Sofola, J. A. (1970). What's in a name: The sociological uses of names and naming among the Yorubas and Igbo ethnic groups in Nigeria. Ibadan, 12(1), 115-132.

The Gale Group Inc. (2003) Yoruba: Yoruba families. Retrieved from http://www.encyclopedia.com/topic/Yoruba. aspx

UCLA Language Materials Project. (2014). Center for World Languages. Retrieved from http://www.lmp.ucla. edu/Profile.aspx?LangID $=22 \& m e n u=004$

Yule, G. (1985). The study of language. Cambridge, UK: Cambridge University Press.

Yule, G. (2016). The Study of Language. Cambridge, UK: Cambridge University Press. doi:10.1017/ CBO9781316594131

Yusuf, N., Olatunji, A., \& Issah, M. (2014). Yoruba names as reflection of people's cultural heritage. In S. A. Ahmad et al. (Eds.), Bringing our cultures homes: Festschrift for Bade Ajayi at 70 (pp. 186-196). Ilorin, NG: Chridamel Publishing House.

Yuzhannikova, M. A. (2015). A typology of linguistic. Journal of Siberian Federal University, Humanities \& Social Sciences, 3(8), 533-541. doi: 10.17516/1997-1370-2015-8-3-533-541

Zapata Becerra, A. A. (2007). Types of words and word-formation processes in English: Inglés IV. Retrieved from http://webdelprofesor.ula.ve/humanidades/azapata/materias/english_4/unit_1_types_of_words_and_word_ formation_processes.pdf 